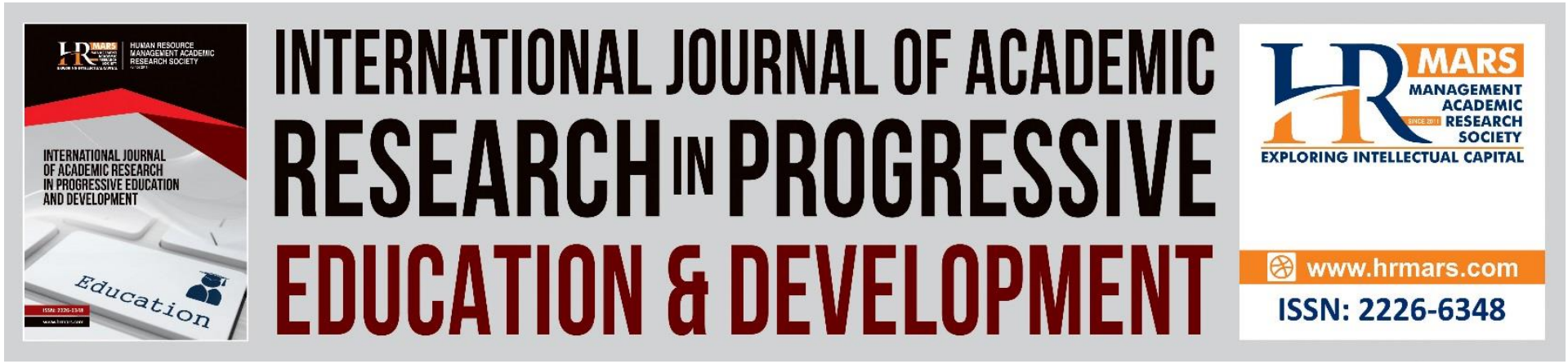

\title{
A Study on the Relationship between Family Peer Group Media and Career Decision Making among Undergraduates in Nigeria
}

Salisu Yunusa, Wan Marzuki Bin Wan Jaafar, Asmah Ismail, Wan Norhayati Binti Wan Othman

To Link this Article: http://dx.doi.org/10.6007/IJARPED/v11-i1/11971 DOI:10.6007/IJARPED/v11-i1/11971

Received: 20 November 2021, Revised: 23 December 2021, Accepted: 07 January 2022

Published Online: 27 January 2022

In-Text Citation: (Yunusa et al., 2022)

To Cite this Article: Yunusa, S., Jaafar, W. M. B. W., Ismail, A., \& Othman, W. N. B. W. (2022). A Study on the Relationship between Family Peer Group Media and Career Decision Making among Undergraduates in Nigeria. International Journal of Academic Research in Progressive Education and Development, 11(1), 319330.

Copyright: (C) 2022 The Author(s)

Published by Human Resource Management Academic Research Society (www.hrmars.com)

This article is published under the Creative Commons Attribution (CC BY 4.0) license. Anyone may reproduce, distribute, translate and create derivative works of this article (for both commercial and non-commercial purposes), subject to full attribution to the original publication and authors. The full terms of this license may be seen at: http://creativecommons.org/licences/by/4.0/legalcode

Vol. 11(1) 2022, Pg. $319-330$

http://hrmars.com/index.php/pages/detail/IJARPED

JOURNAL HOMEPAGE

Full Terms \& Conditions of access and use can be found at http://hrmars.com/index.php/pages/detail/publication-ethics 


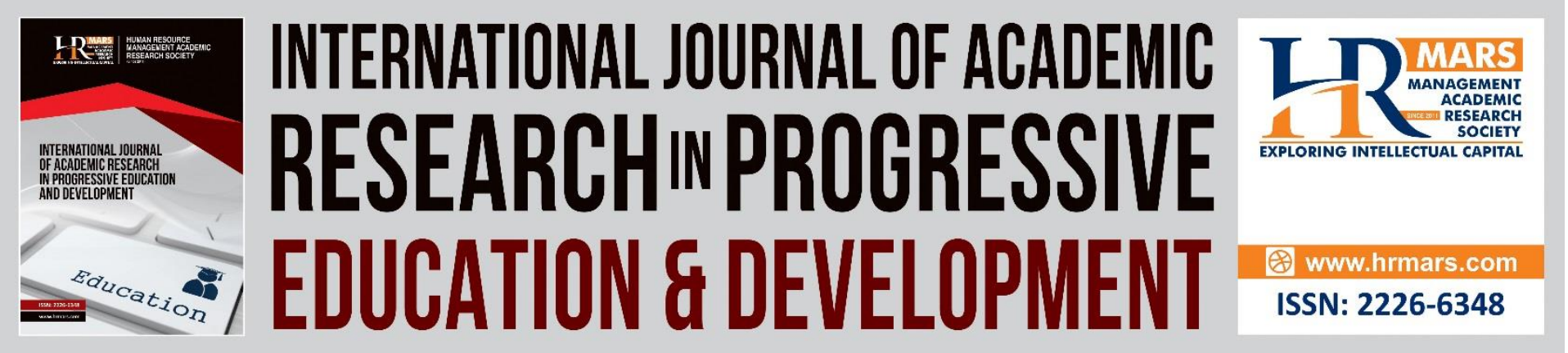

\title{
A Study on the Relationship between Family Peer Group Media and Career Decision Making among Undergraduates in Nigeria
}

\author{
Salisu Yunusa, Wan Marzuki Bin Wan Jaafar, Asmah Ismail, \\ Wan Norhayati Binti Wan Othman
}

Department of Counsellor Education and Counselling Psychology, Universiti Putra Malaysia. Email: gs55022@student.upm.edu.my Corresponding Author,wanmarzuki@upm.edu.my, asmahis@upm.edu.my,wannorhayati@upm.edu.my,

\begin{abstract}
This paper examines relationships between family, peer group, media and career decision making among undergraduate students in nigeria. A quantitative correlational research design was utilized. 1,200 undergraduates form the population while 373 constitute the sample size of the study. The instruments used are factors influencing undergraduate students' career decision making questionnaire with a reliability coefficient $(\alpha=.853)$ and career decision making self-efficacy short form questionnaire $(\alpha=.919)$. Structural equation modelling (sem) by using smart partial least squares (smart-pls 3.2.9) show that family and career decision making has highest significant path ( $t=3.828),(\beta=0.197)$ and $(p=0.000)$ and the second highest significant path is media and career decision making ( $t=2.806),(\beta=0.129)$ and $(p=0.005)$ have significant relationship with career decision making at 0.05 level of significant. It was recommended that parents should support and endorse their children's career choice and not to impose any career that is against their wishes. It was concluded that institutions and non-governmental organization should be organizing regular career guidance program, it will enable students to explore their interests and abilities at an early stage of adolescence that may help them make wise and realistic career decision.
\end{abstract}

Keywords: Career Decision Making, Family, Peers, Media, Motivation and Undergraduate Students

\section{Introduction}

Career decision-making is one of the most difficult tasks confronting students around the world, and Nigeria is no different. Individuals' confidence in their capacity to engage in and complete tasks connected with making and committing to a career choice is referred to as career decision-making (Taylor \& Betz, 1983). Any decision has long-term or short-term consequences in an individual's life, including career decisions. A variety of factors, including learning experience, ambient conditions, task approach, and genetic endowments, may influence this decision (Krumboltz et al., 1976). Any career that does not match the interests and abilities of students may result in poor performance or low self-esteem. Many studies 
reveal that students all over the world encounter a difficulty while deciding on a career path at some time in their life (Bandura, 2001). A person's career decisions are influenced by a variety of factors, but this study focuses solely on family, peer group, and the media as motivational factors that have a relationship with choosing a career as an undergraduate. Choosing courses of study and subsequent career pathways can be a nightmare for prospective undergraduate students in most situations (Edomwonyi, 2018). Nigeria is Africa's most populous country, with over 180 million people, and it has significant issues in determining realistic career selections for its rapidly rising population (Adeyanju, Mogaji, Olusola, \& Oyinlola, 2020). For an individual to have a wise and realistic career, he must understand his strengths and weaknesses. Understanding them will help him to achieve his goal. His goal will be his source of motivation, (Korkmaz \& Kirdok, 2022).

\section{Problem Statement}

According to (Ched, 2008), referenced by (Khasmohammadi, 2018), 40 percent of registered students in numerous African and Asian nations, such as South Africa and the Philippines, drop out or fail to complete their studies in their first year. Nigeria is no different. Many students' poor career choices in Nigeria have been attributed to their ignorance and illiteracy, as well as parental or other pressure (Omoponle, 2019; Babatunde, 2018). It is also noted that there are instances where students enrol in specific programmes only to learn later that they are uninterested in the field (Koech et al., 2016) This means that a situation that arises as a result of a wrong career choice is not in line with the interests and abilities of the students. In many instances, students were influenced or motivated by their family, peer group, or media in making career decisions. In order to make wise and realistic career decisions, IPaye 2016, strongly recommends students should consult a counsellor, as referenced by (Kazi \& Akhlaq, 2017). Consulting a counsellor refers to dialogue with peers, discussion with family (parents), teachers on career decisions, and attending a career conference or career convention. For them, a career conference is a source of career information that includes:

a) To give a platform for students, parents, and counsellors to share their perspectives.

b) To assist in the provision of or shortlisting of desirable careers

c) To provide information about potential career areas and areas of interest.

Making the wrong career decision can harm one's psychology and emotions, as well as their financial situation (Mohd et al., 2010). The family provides students with all necessary support that would serve as the basis for the influence or given order, whereas peer groups are significant aspects of the socialization process and have earned widespread recognition for their impact and pressure in shaping the course of an individual's life through advice. While young people frequently use the mass media, particularly television, newspapers, and social media websites, to explore about various careers, employment, and other issues. Students are exposed to a variety of lifestyles, global issues, trends and fashions, politics, culture, economic issues, documentaries, dramas, or movies depicting careers such as medicine, geography, and law, among others, through the media. All of these can encourage students to pursue any career. Children know more about real life and television careers than other professions, according to (Wroblewski \& Huston, 1987) because television serves as a source of occupational and vocational information. Because it commonly depicts work-related activities of fictitious characters, television is one of the most important sources of youth employment education. The purpose of this study is to investigate more about the relationships between factors that determine career decisions making. Despite the fact that there are numerous factors that determine career decisions, this study attempts to identify 
DEVELOPMENT

Vol. 11, No. 1, 2022, E-ISSN: 2226-6348 @ 2022 HRMARS

the relationships between family, peer group, media and career decision making among Nigerian undergraduate students.

\section{Literature Review}

\section{Social Learning Theory of Career}

The Social Learning Theory of Career Decision Making (SLTCDM) of Krumboltz (1976) explained the factors that determine career choice. In general, the theory aimed to describe factors that influenced career decisions, measure how confident students were in their career choices, assess the preparedness of institutions in career selection, and learn about students' and teachers' perspectives on career decisions (Ngunjiri, 2013). The Social Learning Theory of Job Decision Making (SLTCDM) focuses into the factors that influence career choices. Genetic endowments and special abilities, environmental conditions and events, learning experiences, and task approach skills are the most important determinants (Krumboltz et al., 1976). This research looked at environmental variables and events that are normally out of a person's control. They include the number and nature of career and training opportunities, social policies and procedures for selecting trainees and workers, the rate of return for various occupations, labour laws and union rules, natural disasters such as earthquakes, droughts, floods, and hurricanes, natural resource availability and demand, technological developments, changes in social organisation, and more (Suryani \& George, 2021). The following factors are included in the study's environmental conditions: family, peer groups, and the media.

\section{Family Factor and Career Decision Making}

This research considers families as fathers and mothers, which are the sources of motivation for their children that can easily influence their career decisions. Several studies show that parents have a substantial influence on their children's career choices. For instance, in Nigeria (Ogunyewo, Afemikhe, Ajio, \& Olanlesi-aliu, 2014), (Ezeweani \& Atomatofa, 2012), (Egunjobi, Salisu, \& Ogunkeye, 2014), in Tanzania (Amani, 2016) in Kenya (Obwoge \& Kibor, 2016). Semistructural interviews with 23 postgraduate students were conducted by (Adefulu, Farinloye, \& Mogaji, 2020) on study on factors impacting postgraduate students' university choice in Nigeria, Parents have a statistical significant influence on their children's professional choices, according to research. (Zhang et al., 2021), observed that family suggestions (OR $=1.25,95$ percent $\mathrm{Cl}=1.08-1.46$ ) correlated positively with students' choice of psychiatry as a career in a study on career choice and influential factors among Chinese medical students specialising in psychiatry. This shows that family has significant relationship with career decision of psychiatric students. Career Aspiration of Students: The Influence of Peers, Teachers, and Parents in Ghana (Owusu, Owusu, Fiorgbor, \& Atakora, 2021), discovered that parents had an influence on their children's career aspirations. The parents believed that their children should not make career selections without first seeking their permission ( $M=3.32, S D=1.43)$. This suggested that parents were encouraging their children to make decisions they agreed with. This demonstrates that parents are concerned about their children's careers and that their children do not make career selections without their permission.

\section{Peers Group and Career Decision Making}

The first out-of-home social group in which students, or children, seek approval and recognition is the peer group. Peers were also seen as motivational factors; they motivate and influence each other's career decisions. According to Harris and Grede (1977), a child's 
peer group has a significant impact on their intellectual and personal development. Several long-term research back up claims that peer groups have a significant impact on students' career choices. It is understandable that some students enrol in certain programmes of study since their friends are also enrolled. Such students may struggle to achieve effectively since their options do not align with their interests or abilities. Factors Influencing Undergraduate Students' Career Choices in Kenyan Public Universities, by (Koech et al., 2016), used 210 students as the sample. A self-administered questionnaire was utilised to collect data, and it included both open-ended and closed-ended items. There is a correlation between peer influence and career choice $(r=0.464, p=0.000)$, according to the findings. This indicates that there is a direct relationship between career choice and peer advice. In contrast, it was discovered in another study (Owusu et al., 2021) Career Aspirations of Students: The Influence of Peers, Teachers, and Parents in Ghana that peers do not have significant relationships with their friends' career aspirations $[F(195)=2.173, p>.05]$.

\section{The Media and Career Decision Making}

Young people frequently use the mainstream media, notably television, newspapers, and social media websites, to learn about various professions, job markets, and other life-related matters. This has ignited students' interest and motivated them to make career decisions. Factors influencing students' career choices were investigated with 432 students from two public-sector universities in Lahore, Pakistan, in a study by Kazi and Akhlaq (2017), A questionnaire and in-depth interviews were used to gather information. According to the findings, internet information was determined to be quite important (72 percent) in influencing the students' career choice.

Another study conducted by (Lordly \& Dubé, 2012): was titled: The Who, What, When, and How of Choosing a Dietetics Career Using Survey Methods: Dietetics programme students $(n=397)$ were given a survey form to fill out in class and online. Descriptive statistics were used to analyse the data, It was discovered that they made their decision based on information gathered through the media (50 percent). More over half of them agreed that the media has a significant impact on their professional decisions.

\section{Conceptual Model}

Considering the reviewed literature, identified problems, and underlying theory above, the following framework (figure 1) was developed to support the present study.

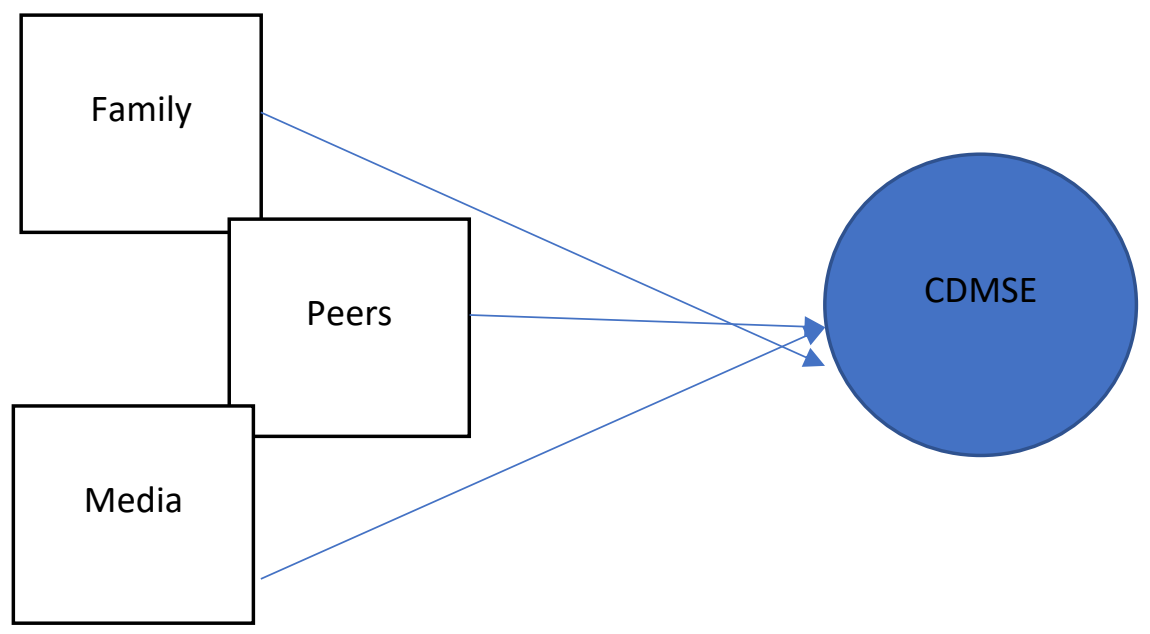

Figure One. Conceptual Model 
DEVELOPMENT

Vol. 11, No. 1, 2022, E-ISSN: 2226-6348 @ 2022 HRMARS

\section{Objectives of the Study}

The major aim of this research is to look into the connections between family, peer group, media, and career decisions making among undergraduate students in Jigawa State, Nigeria. To accomplish the overall objectives, this study was designed to achieve the following specific objectives and hypotheses:

$>$ To find out the relationship between family and career decision making among undergraduate students in Jigawa State Nigeria.

$>$ To determine the relationship between peer group and career decision making among undergraduate students in Jigawa State Nigeria.

$>$ To determine the relationship between media and career decision making among undergraduate students in Jigawa State Nigeria.

\section{Hypotheses}

The study answers the following research hypotheses:

$\mathbf{H}_{1}$. There is a significant relationship between family and career decision making among undergraduate students in Jigawa State Nigeria.

$\mathbf{H}_{\mathbf{2}}$. There is a significant relationship between peers group and career decision making among undergraduate students in Jigawa State Nigeria

$\mathbf{H}_{\mathbf{3}}$. There is a significant relationship between media and career decision making among undergraduate students in Jigawa State Nigeria

\section{Methodology}

A quantitative correlational research design was used in this study. The study examines the relationship between family, peer group, media, and career decision-making among undergraduate students in Jigawa State, Nigeria, using a correlational design. A total of 1,200 undergraduate students from Sule Lamido University and Federal University Dutse participated in the study. A total of 373 undergraduate students were included in the study. The pupils were chosen at random and in a systematic manner. One student was chosen out of every three to complete the surveys.

\section{The Instrument}

A quantitative correlational research design was used in this study. The study's data collection instruments are factors influencing undergraduate students' career decision decision making (IVs) and career decision making self-efficacy (DV). The 45-item questionnaire is used to look into the relationships between family, peers, and the media (IVs), as well as career decisionmaking (DV). From 4 (strongly agree) to 1 (strongly disagree), a 4-point Likert scale was used (IVs). A 5-point Likert scale ranges from full confidence to no confidence at all on the second questionnaire for (DV). The content validity of the instruments was assessed by two experts. The instruments were pilot-tested for internal consistency by the researchers the (IVs has 20 items $\alpha=.852$ ) and (DV has 25 items $\alpha=919$ ), suggesting that they were valid and reliable for examining the connections between family, peers, media, and career decision-making. The students were given the instruments after the researchers explained the purpose of the study to them. The questionnaires took the students 30-40 minutes to complete.

\section{The Result of the findings}

THE FACTOR LOADINGS/OUTER LOADINGS OF EACH ITEMS CALCULATED THROUGH PLSALGORITHM 


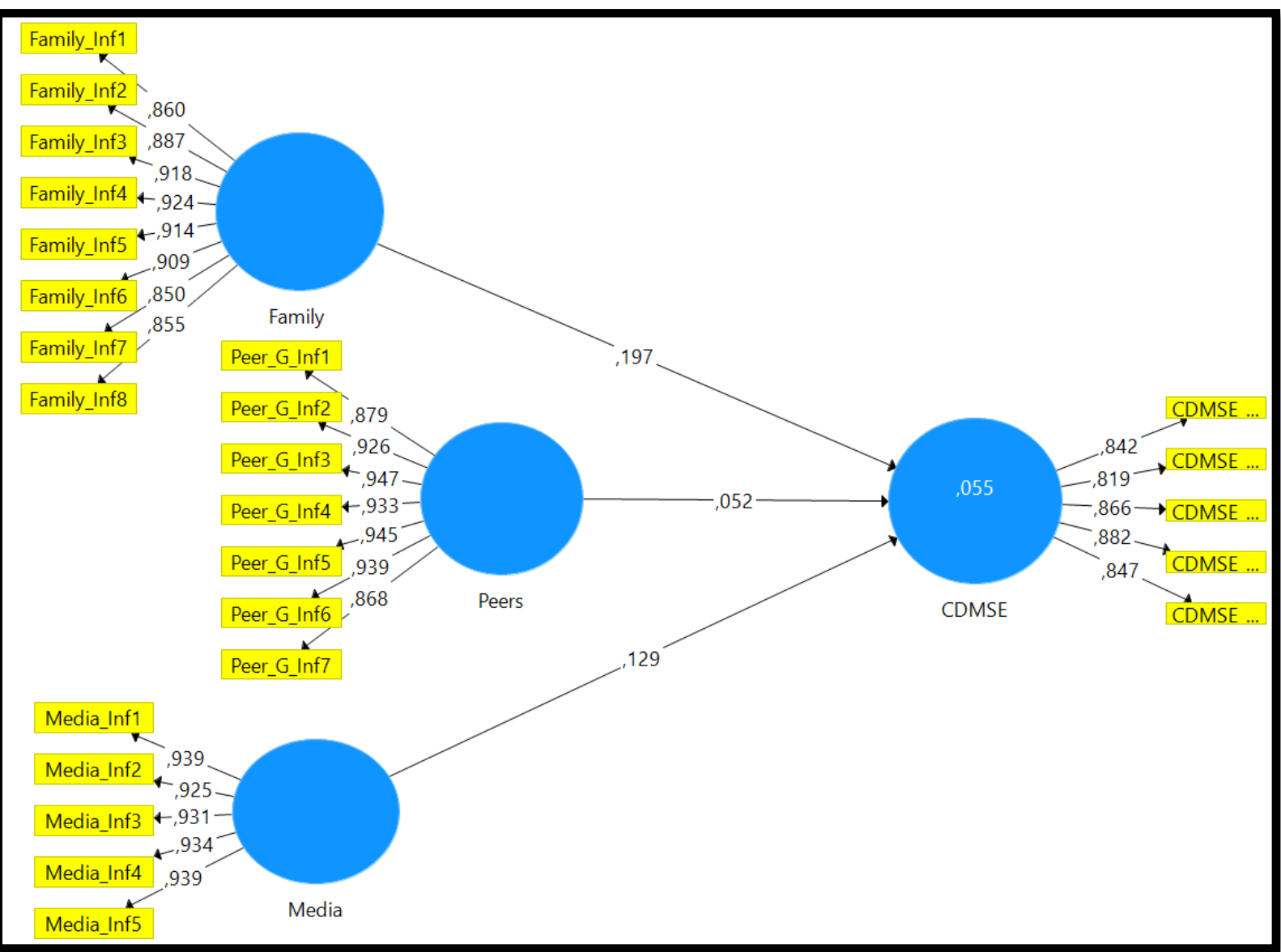

4.2 Table 1. Internal consistency and convergent Validity

\begin{tabular}{|c|c|c|c|c|}
\hline Factor/Items & Factor Loading & $\begin{array}{l}\text { Cronbach's } \\
\text { Alpha }\end{array}$ & $\begin{array}{l}\text { Composite } \\
\text { Reliability }\end{array}$ & $\begin{array}{l}\text { Average } \\
\text { Variance } \\
\text { Extracted (AVE) }\end{array}$ \\
\hline CDMSE & & 0.905 & 0.929 & 0.725 \\
\hline CDM1. & 0.842 & & & \\
\hline CDM2. & 0.819 & & & \\
\hline CDM3. & 0.866 & & & \\
\hline CDM4. & 0.882 & & & \\
\hline CDM5. & 0.847 & & & \\
\hline Family & & 0.963 & 0.968 & 0.792 \\
\hline Family1. & 0.860 & & & \\
\hline Family2. & 0.887 & & & \\
\hline Family3. & 0.918 & & & \\
\hline Family4. & 0.924 & & & \\
\hline Family5. & 0.914 & & & \\
\hline Family6. & 0.909 & & & \\
\hline Family7. & 0.850 & & & \\
\hline Family8. & 0.853 & & & \\
\hline Peer Group & & 0.970 & 0.975 & 0.846 \\
\hline
\end{tabular}




\begin{tabular}{lllll}
\hline Peer 1. & 0.879 & & & \\
Peer 2. & 0.926 & & \\
Peer 3. & 0.947 & & \\
Peer 4. & 0.933 & & & \\
Peer 5. & 0.945 & $\mathbf{0 . 9 7 1}$ & \\
Peer 6. & 0.939 & $\mathbf{0 . 9 6 3}$ & & \\
Peer 7. & 0.868 & & & \\
\hline Media & & & & \\
Media1. & 0.939 & & & \\
Media2. & 0.925 & & & \\
Media3. & 0.931 & & & \\
Media4. & 0.934 & & & \\
Media5. & 0.939 & & & \\
\hline
\end{tabular}

Discriminant validity, on the other hand, demonstrates how distinct one construct is from others. The discriminant validity was assessed using the Heterotrait-Monotrait Ratio (HTMT). The HTMT values must be less than 0.85, according to (Kline, 2011). However, because the value is less than 0.85 , the upper threshold value for the current study was 0.194 , as indicated in table 2 , in order to comply with the discriminant validity.

Table 2. Heterotrait- Monotrait Ratio (HTMT)

\begin{tabular}{lllll}
\hline Construct & CDMSE & Family & Media & Peer Group \\
\hline CDMSE & & & & \\
Family & 0.194 & & & \\
Media & 0.120 & 0.071 & & \\
Peer Group & 0.057 & 0.054 & 0.045 & \\
\hline
\end{tabular}

According to (Hair, Risher, Sarstedt, \& Ringle, 2019), all of the conditions have been met, and the criterion to test the present study relationships has also been met, based on the results of the tables above. To estimate $t$ statistics and confidence intervals, the bootstrapping procedure was used. The path coefficient assessment results are presented in Table 3 and Figure 3 , where the provided hypotheses reveal that two are significant while one is not. At the 0.05 level, the supporting hypothesis was statistically significant. 


\section{Structural Model With T-Values (Bootstrapping Result) Displayed the Direct Relationships}

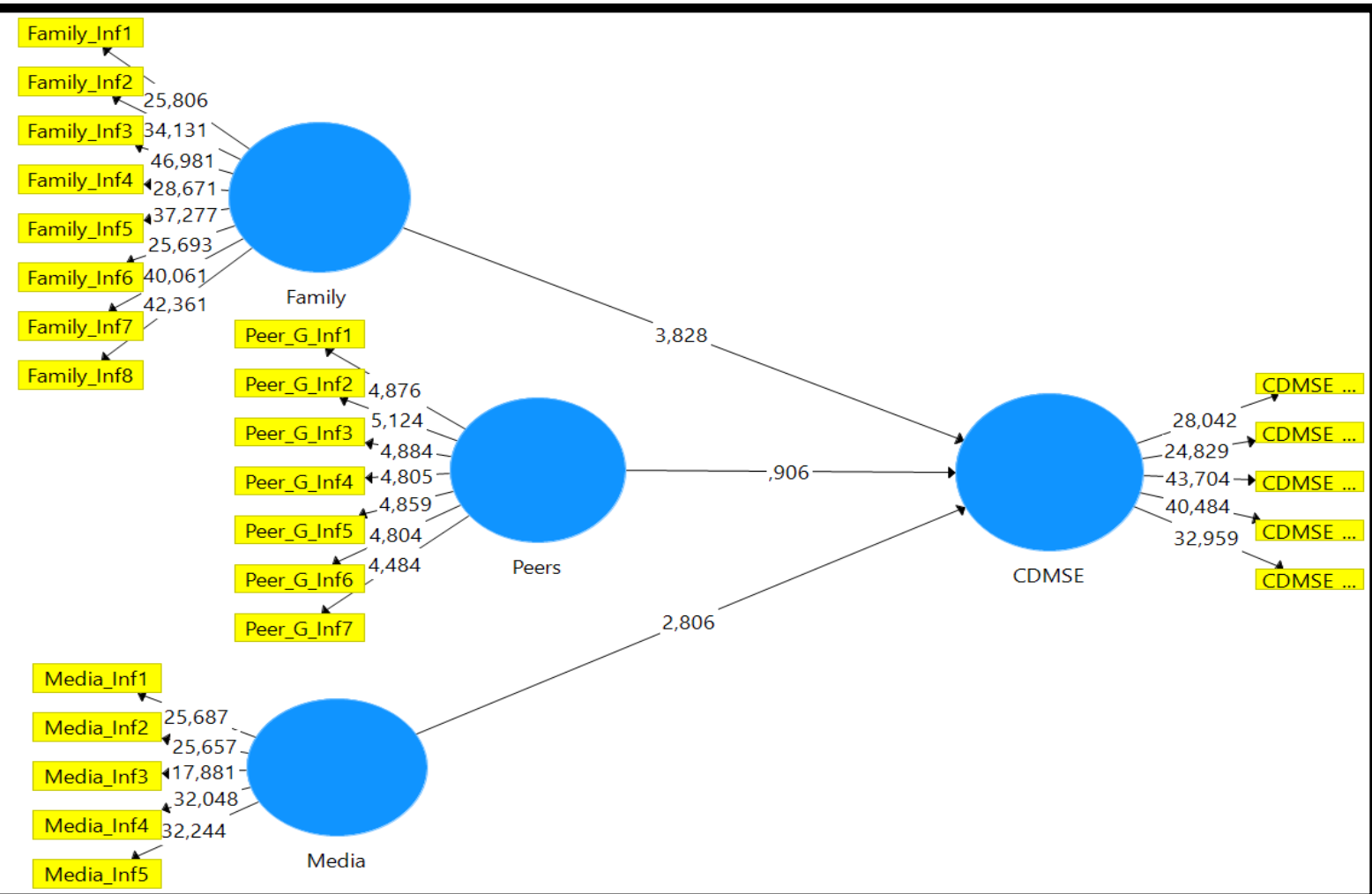

Figure 3. Structural model with t-values

Table 3. Path coefficient result (Direct effect) Assessment of Structural Model Analysis

\begin{tabular}{lllllll}
\hline Hypotheses & SM & SD & $\begin{array}{l}\text { OS/Bet } \\
\mathbf{a}\end{array}$ & $\mathbf{T}$ & $\begin{array}{l}\text { Value } \\
\text { S }\end{array}$ & Decision \\
\hline H1: Family -> CDM & 0.206 & 0.052 & 0.197 & 3.828 & 0.000 & Significant \\
H2: Peer Group -> CDM & 0.059 & 0.057 & 0.052 & 0.906 & 0.365 & $\begin{array}{l}\text { Not } \\
\text { Significant }\end{array}$ \\
H13 Media -> CDM & 0.139 & 0.46 & 0.129 & 2.806 & 0.005 & Significant \\
\hline
\end{tabular}

Note: CDM: Career Decision Making; OR: Original Sample; SM: Sample Mean; SD: Standard Deviation; Significant: $p<0.05$

Table 4. Summary of all hypotheses results

\begin{tabular}{|l|l|l|}
\hline No. & Hypotheses & Results \\
\hline H1 & Family -> CDM & Accepted \\
\hline H2 & Peer Group -> CDM & Not Accepted \\
\hline H3 & Media -> CDM & Accepted \\
\hline
\end{tabular}

Note: Career Decision Making 
DEVELOPMENT

Vol. 11, No. 1, 2022, E-ISSN: 2226-6348 @ 2022 HRMARS

\section{Contribution of the Study}

1. Firstly, Family has a significant relationship with career decision-making among undergraduates in Nigeria. They should provide career information, support, encourage, and endorse their children's career choices.

2. Secondly, Peer groups have no significant relationship with career decision-making among undergraduates in Nigeria. Peers should not give career advice to their friends; instead, they should encourage them to seek help from the guidance and counselling office.

3. Thirdly, The media is a significant factor in students' career decision-making among undergraduates in Nigeria. Careers should be promoted in print and electronic media by highlighting the benefits, privileges, and criteria or qualification requirements of each job. That would aid in making informed professional choices.

\section{Discussion of the Findings}

The results of this study demonstrate that family (parents) has a significant relationship with career decision making ( $t=3.828),(=0.197)$, and $(P=0.000)$. (Zhang et al., 2021) and (Owusu et al., 2021), both found similar findings, parents want their children to have a nice life and earn a good salary, so they encourage and drive them to choose occupations.

The study also found that peer groups have no significant link with career decision-making, as seen by the findings ( $t=0.906),(=0.052)$, and $(P=0.365)$. (Owusu et al., 2021) came to the same conclusion. Peers do not have statistically significant relationships with their friends' career aspirations, according to the researchers. Peer counselling, peer contact, peer mentoring, and peer connections were all ways in which students were influenced by their peers. Friends help each other feel at ease and calm, allowing them to be easily influenced by one another. Unlike previous research, this study discovered that peer groups have no statistically significant relationship with career decisions.

Finally, as revealed by the path coefficient in Table 1, the media is a significant factor in students' career decisions, $(p=0.005)$. The findings are consistent with those of (Valek \& Al Buainain, 2016) and (Lordly \& Dubé, 2012), who found that print and electronic media have a significant impact on students' career decisions. When it came to choosing a career, students were affected by newspapers, books, movies, characters, and the internet.

\section{Conclusion}

The study concludes that institutions and non-governmental organisations should actively arrange regular career guidance programmes, such as career guidance days, to assist students recognise their strengths and weaknesses at an early stage. This exposure and understanding of oneself will aid them in making realistic career decisions that match their interests and abilities'.

\section{Recommendations}

The following suggestions are given based on the findings:

Parents should provide career information, support, encourage and endorse their children's career choices, but not impose any career on them that they do not want. Forcing them to pursue a career against their will may result in poor academic achievement or low selfesteem, which can lead to a lack of confidence in their ability to succeed in their chosen career.

Peers should not provide their friends career advise; instead, they should urge them to seek career assistance from the guidance and counselling office. A professional school counsellor 
is more qualified to provide reliable career information to assist students in determining career choices. Career satisfaction will be enhanced with proper advice from a counsellor, and they will be protected from potential career stress or career maladjustment.

Professions should be promoted through the media, both print and electronic, by explaining the benefits, privileges, and criteria or qualification requirements of each career. This understanding will assist students in better planning their academic programme and obtaining the necessary training before embarking on their chosen career.

\section{References}

Adefulu, A., Farinloye, T., \& Mogaji, E. (2020). Factors Influencing Postgraduate Students' University Choice in Nigeria. In Higher Education Marketing in Africa (pp. 187-225): Springer.

Adeyanju, S., Mogaji, E., Olusola, J., \& Oyinlola, M. (2020). Factors influencing students' choice of a federal university: a case study of a Nigerian federal university. In Higher Education Marketing in Africa (pp. 135-163): Springer.

Amani, J. (2016). Do Tanzanian Undergraduate Students Choose or Hunt for Their Degree Programmes? International Journal of Higher Education, 5(2), 74-81.

Babatunde, J. O. (2018). Effectiveness of guidance and counselling strategies at promoting career decision making among youths in Nigeria

International Research Journals Vol. 9(5) ((ISSN: 2141-5161)), pp. 151-156, December, 2018Copyright

Bandura, A. (2001). Social cognitive theory: An agentic perspective. Annual review of psychology, 52(1), 1-26.

Edomwonyi, J. (2018). Influence of self-efficacy antecedents on career decision-making among business education students in federal universities in south southern, Nigeria.

Egunjobi, A. F., Salisu, T. M., \& Ogunkeye, O. I. (2014). Academic profile and career choice of fresh undergraduates of library and information science in a Nigerian University of Education. Annals of Library and Information Studies (ALIS), 60(4), 296-303.

Ezeweani, U., \& Atomatofa, R. (2012). Choosing a career in science: The Nigerian student perception. International Journal of Research Studies in Educational Technology, 1(2), 73-81.

Hair, J. F., Risher, J. J., Sarstedt, M., \& Ringle, C. M. (2019). When to use and how to report the results of PLS-SEM. European business review.

Kazi, A. S., \& Akhlaq, A. (2017). Factors Affecting Students' Career Choice. Journal of Research \& Reflections in Education (JRRE), 11(2).

Khasmohammadi, M. (2018). Influence of Career Decision-Making Self-Efficacy, Career Maturity, Parenting Style, And Parental Perfectionism on Career Decision Among Undergraduate Students. In: UPM.

Kline, R. B. (2011). Convergence of structural equation modeling and multilevel modeling. In: na.

Koech, J., Bitok, J., Rutto, D., Koech, S., Okoth, J. O., Korir, B., \& Ngala, H. (2016). Factors influencing career choices among undergraduate students in public universities in Kenya: A case study of university of Eldoret. International Journal of Contemporary Applied Sciences, 3(2), 50-63.

Korkmaz, Ozan, \& Kirdok, Oğuzhan. (2022). CAREER ADAPTABILITIES IN UNIVERSITY STUDENTS: EXAMINING THE PREDICTION OF CAREER GOAL FEEDBACK AND LIFE GOALS. MOJES: Malaysian Online Journal of Educational Sciences, 10(1), 1-10. 
Krumboltz, J. D., Mitchell, A. M., \& Jones, G. B. (1976). A social learning theory of career selection. The counseling psychologist, 6(1), 71-81.

Lordly, D., \& Dubé, N. (2012). The who, what, when, and how: of choosing a dietetics career. Canadian Journal of Dietetic Practice and Research, 73(4), 169-175.

Mohd, F., Salleh, A. M., \& Mustapha, R. (2010). The influence of contextual aspects on career decision making of Malaysian technical students. Procedia-Social and Behavioral Sciences, 7, 369-375.

Ngunjiri, G. F. (2013). Decisiveness in Career Choices among Secondary School Students in Kiambu West District-Kiambu County, Kenya. School of Education in Partial Fulfillment for the Requirements for Award of Degree of Master of Education, Kenyatta University.

Obwoge, M. E., \& Kibor, S. J. (2016). Factors influencing trainee career choice in TVET institutions in North Rift Kenya. IRA-International Journal of Management \& Social Sciences, (3):476-485.

Ogunyewo, O. A., Afemikhe, J. A., Ajio, D. K., \& Olanlesi-aliu, A. (2014). Adolescents' perception of career choice of nursing among selected secondary schools in Jos, Nigeria.

Omoponle, A. H. (2019). Religiosity, Family Back Ground and Occupational Prestige as Predictors of Career Preference Among Secondary School Adolescents in Osun State. American Journal of Psychology and Behavioral Sciences, 6(2), 8.

Owusu, M. K., Owusu, A., Fiorgbor, E. T., \& Atakora, J. (2021). Career Aspiration of Students: The Influence of Peers, Teachers and Parents. Journal of Education, Society and Behavioural Science, 67-79.

Suryani, A., \& George, S. (2021). "Teacher education is a good choice, but I don't want to teach in schools." An analysis of university students' career decision making. Journal of Education for Teaching, 1-15.

Taylor, K. M., \& Betz, N. E. (1983). Applications of self-efficacy theory to the understanding and treatment of career indecision. Journal of Vocational Behavior, 22(1), 63-81.

Valek, N. S., \& Al Buainain, A. A. (2016). The influence of media implemented into the eventtourist career model: TriYas triathlon, Abu Dhabi. Tourismos, 11(5).

Wroblewski, R., \& Huston, A. C. (1987). Televised occupational stereotypes and their effects on early adolescents: Are they changing? The Journal of Early Adolescence, 7(3), 283297.

Zhang, Y.-J., Yuan, K., Chang, S.-H., Yan, W., Que, J.-Y., Deng, J.-H., . . An, C.-X. (2021). Career choice and influential factors among medical students majoring in psychiatry in China. BMC medical education, 21(1), 1-12. 